\title{
Association of occupational exposure on semen density in male industrial workers undergoing infertility treatment at tertiary care hospital
}

\author{
Leena Wadhwa', Ashish Fauzdar ${ }^{1 *}$, Sanjana N. Wadhwa², Lata Singh², Sumit Chakravarti, \\ Onkar Kaur ${ }^{4}$
}

${ }^{1}$ IVF and Fertility Research Centre, Department of Obstetrics and Gynaecology, ESIC-PGIMSR Model Hospital, Basaidarapur, New Delhi, India

${ }^{2}$ Department of Obstetrics and Gynaecology, ${ }^{3}$ Department of Surgery, ${ }^{4}$ Department of Pathology, ESIC-PGIMSR Model Hospital, Basaidarapur, New Delhi, India

Received: 10 April 2019

Accepted: 08 May 2019

\section{*Correspondence:}

Dr. Ashish Fauzdar,

E-mail: ashishfauzdar@gmail.com

Copyright: ( ) the author(s), publisher and licensee Medip Academy. This is an open-access article distributed under the terms of the Creative Commons Attribution Non-Commercial License, which permits unrestricted non-commercial use, distribution, and reproduction in any medium, provided the original work is properly cited.

\begin{abstract}
Background: Working with particular substances or under certain working situations may cause some workers to experience abnormalities in their sexual or reproductive health. Occupational exposures can lead to infertility, but the workers may not be aware of such problems. The purpose of the study was to determine the association between male infertility and occupation of industrial workers in organized sector.

Methods: Prospective case-controlled study that included 136 industrial workers working in organized sector and attending infertility clinic for treatment. This study included male partners aged between 21-46 years with primary or secondary infertility and undertaking same occupation for at least last three months. Complete infertility workup of all male partners attending infertility clinic was done that included detailed history and information related to occupation. Routine semen parameters were evaluated according to the 2010 World Health Organization (WHO) criteria.

Results: In the present study, significant semen abnormalities were observed in male partners with age more than 31 years and undertaking arduous jobs for more than 5 years $(\mathrm{p}<0.05)$ in study group $(\mathrm{n}=136)$ as compared to control group $(n=62)$. The abnormal semen count was observed in $114(83.2 \%)$ workers in the study group that included 43 $(31.6 \%)$ with total sperm concentration (TSC) less than 10 million/ml and azoospermia in $44(32.3 \%)$. Reduced motility (asthenozoo-spermia) was observed in majority 125 (91.9\%) of male partners. The findings were significant $(\mathrm{p}<0.05)$ as compared to control group.

Conclusions: Preventive measures in the workplace need to be established to reduce the effect of occupational hazards and its influence in the semen parameters ultimately leading to infertility.
\end{abstract}

Keywords: Male Infertility, Occupational Hazards, Oligoasthenozoospermia, Semen parameters

\section{INTRODUCTION}

There have been several studies in past decade that have focused on the investigation of seminal quality including a metaanalysis that showed that sperm density had declined globally by about $50 \%$ during the second half of the last century and attracted significant attention and have been a matter of debate. ${ }^{1}$ It is suggested that the 
increased frequency of male reproductive abnormalities is due to adverse effects of environmental or lifestyle factors, such as occupational and environmental exposures, medications, and sexually transmitted diseases. $^{2,3}$ In last quarter of century there has been intensive industrialization, urbanization, population growth and extensive usage of pesticides in agriculture. There are many studies that suggest that the living condition of males play a significant role in spermatogenesis and hormonal metabolism disorders due to pollution of air, water and earth. ${ }^{4-6}$ Working with particular substances or under certain working condition may cause some workers to experience abnormalities in their sexual or reproductive health.

The occupational exposures can lead to infertility, but the workers may not be aware of such problems. There could be strong association with occupation of industrial workers influencing semen parameters underdoing infertility treatment. Exposure to occupational hazards can cause changes in the sex drive of men and women, which can inhibit or prevent fertilization. It can also damage the eggs or sperm, cause changes in the genetic material carried by the eggs and sperm (which can result in birth defects), and cause cancer or other diseases in the reproductive organs of men or women. Spermatogenesis disruption can occur with occupational exposure to organic solvents which are widespread in industrial workers. Because of the inherent difficulties of conducting such studies in industrial populations few systematic studies have been carried out on the study of workplace hazards and their effects on male reproductive function. The hypothesis for the study was possible association of male infertility with the occupation of industrial workers undergoing infertility treatment. The main objective of the study was to determine the association between occupation and semen parameters of males working as industrial workers attending infertility clinic.

\section{METHODS}

Prospective case-controlled study to test the hypothesis whether there is association of male infertility with occupation of industrial workers and included male partners attending infertility clinic between years July 2012 to August 2017. In total study included 136 male partners of the sub-fertile couples working in organized industrial sector and 62 male partners in control group. Couples attended the infertility clinic for evaluation of infertility and treatment at a tertiary care hospital during the period of 5 years.

The case control study was carried out in three stagesfirst stage was conducted using a questionnaire devised by the authors of the study, the second and third stages were physical examination and evaluation of male semen parameters respectively. The questionnaire used in the study consisted of two sections. The first section included complete infertility workup of all male patients attending the infertility clinic with detailed present, sexual, contraceptive, past and family history taking including smoking, alcohol intake habit. The second part of questionnaire was mainly designed to collect information on respondent's age, type of occupational activity i.e. occupation performed, assessment of work in terms of its arduousness nature i.e. hazardous, arduous or mixed with its possible health hazards and duration of employment in years.

In the second stage of the study physical examination of males was done to evaluate the testicular size and rule out variocoele or any other abnormality. During the third stage of study semen analysis was performed for each male for diagnosing male factor of infertility. The sample was collected after a minimum of 02 days of sexual abstinence through masturbation. The specimen was kept for liquefaction at ambient temperature, between $25^{\circ} \mathrm{C}$ to $37^{\circ} \mathrm{C}$ before routine semen analysis was done as per defined 2010 WHO criteria. Based on the semen analysis patient were allocated into 2 groups, study group with abnormal semen parameters and into control group with normal semen parameters.

After categorizing the groups according to semen analysis, they were represented into various occupations and considering all the jobs mentioned and workplace characteristics. The respondents were divided into three categories were hazardous which were males who performed occupation associated with an increased risk of occurrence of infertility problems $(n=17,12.5 \%)$ i.e. the occupation of farmers using pesticides and herbicides, printing press, glass cutting, zinc polishing, welding, iron steel worker, iron cutter, incinerator worker, tobacco processing, plastic production, smiths etc, Arduous includes males performing occupation which do not increase the risk of occurrence of fertility disorders $(n=65,48 \%)$ i.e. the occupation of hard physical stress, exposure to stress, shift workers, taxi drivers, tailor, labour supervisor, field worker, working at height, sales executive, office clerk, peons, computer operators, security guards, mechanics, refuse removal etc and mixed includes males occupation associated both with increased risk and long working hours i.e. $(n=54,39.5 \%)$ bakers, cloth ironing, factory workers, cooks, construction workers, electronic, mobile repair workers etc.

The study inclusion criteria included male partners of the sub-fertile couple with age between 21-46 years with primary or secondary infertility, BMI between 18-30 $\mathrm{kg} / \mathrm{m}^{2}$ and working in the same occupation for at least last three months. As per exclusion criteria, study excluded male partners with medical disease such as diabetes mellitus, hypertension, mumps, tuberculosis, STD's hydrocele, varicocele, undescended testis, inguinal hernia repair or surgery for hypospadias, congenital absence of vas deferens or some kind of genetic or chromosomal abnormalities. Further study also excluded males taking any psychotropic, anti-epileptics or cardiotropics drugs, 
males having tumors or undergoing chemotherapy that could impair semen parameters.

Categorical variables were presented in number and percentage $(\%)$ and continuous variables were presented as mean \pm SD and median. Qualitative variables were correlated using Chi-Square test/Fishers Exact test. A p value of $<0.05$ was considered statistically significant. The data was entered in MS EXCEL spread sheet and analysis was done using Statistical Package for Social Sciences (SPSS) version 21.0.

\section{RESULTS}

Based on the semen density patient were categorized into 2 groups, study group $(\mathrm{n}=136)$ included patient with abnormal semen parameters with either abnormal total sperm concentration or total motility and control group $(n=62)$ included patient having semen parameters with both total sperm concentration and total motility within range as per WHO standards. The majority of males 72 $(52.9 \%)$ in the study group were aged between $31-46$ years and remaining $64(47.0 \%)$ were age $<31$ years.

Table 1: Baseline demographic variables and semen parameters of occupational workers undergoing infertility treatment.

\begin{tabular}{|c|c|c|c|c|c|c|}
\hline \multirow{2}{*}{ Variables } & & \multicolumn{2}{|l|}{ Group } & \multirow{2}{*}{$\begin{array}{l}\text { Odds Ratio } \\
\text { (OD)* }\end{array}$} & \multirow{2}{*}{$95 \% \mathrm{CI}$} & \multirow{2}{*}{ p-value } \\
\hline & & Cases $(n=136)$ & Control $(n=62)$ & & & \\
\hline \multirow{5}{*}{ Age } & $21-25$ yrs. & $10(7 \%)$ & $12(19.3 \%)$ & 1 & & \\
\hline & $26-30$ yrs. & $54(40 \%)$ & $44(70.9 \%)$ & 1.4 & $0.58-3.7$ & 0.414 \\
\hline & $31-35$ yrs. & $55(40 \%)$ & $4(6.4 \%)$ & 16.5 & $4.4-61.5$ & $<0.0001$ \\
\hline & $36-40 \mathrm{yrs}$. & $13(10 \%)$ & $2(3.2 \%)$ & 7.8 & $1.4-43.0$ & 0.0185 \\
\hline & $>40$ yrs. & $4(3 \%)$ & 0 & 10.7 & $0.5-222.8$ & 0.1256 \\
\hline \multirow{2}{*}{$\begin{array}{l}\text { Type of } \\
\text { infertility }\end{array}$} & Primary infertility & $133(98 \%)$ & $62(100 \%)$ & 1 & & \\
\hline & Secondary infertility & $3(2 \%)$ & 0 & 3.2 & $0.1-64.4$ & 0.4347 \\
\hline \multirow{3}{*}{$\begin{array}{l}\text { Type of } \\
\text { employment }\end{array}$} & Arduous & $65(48 \%)$ & $48(77 \%)$ & 1 & & \\
\hline & Hazardous & $17(12 \%)$ & $14(23 \%)$ & 0.89 & $0.4-1.9$ & 0.7893 \\
\hline & Mixed & $54(40 \%)$ & 0 & 80.7 & $4.8-1339.4$ & $<0.0001$ \\
\hline \multirow{3}{*}{$\begin{array}{l}\text { Total } \\
\text { duration of } \\
\text { employment }\end{array}$} & Less than 5 yrs. & $81(60 \%)$ & $62(100 \%)$ & 1 & & \\
\hline & $5-10$ yrs. & $37(27 \%)$ & 0 & 57.5 & $3.4-955.0$ & $<0.0001$ \\
\hline & More than 10 yrs & $18(13 \%)$ & 0 & 28.3 & $1.6-480.0$ & 0.0204 \\
\hline \multirow{4}{*}{$\begin{array}{l}\text { Total sperm } \\
\text { count (TSC) }\end{array}$} & No sperms & $44(32 \%)$ & 0 & 247.2 & $14.6-4183.9$ & $<0.0001$ \\
\hline & $<10$ million & $43(32 \%)$ & 0 & 241.6 & 14.2-4091.4 & $<0.0001$ \\
\hline & 10-15 million & $27(20 \%)$ & 0 & 152.7 & $8.9-2610.0$ & $<0.0001$ \\
\hline & $>15$ million & $22(16 \%)$ & $62(100 \%)$ & 1 & & \\
\hline \multirow{2}{*}{$\begin{array}{l}\text { Total } \\
\text { motility } \\
(\mathrm{A}+\mathrm{B} \mathrm{CD})\end{array}$} & Normal motility & $11(8.0 \%)$ & $62(100 \%)$ & 1 & & \\
\hline & Abnormal & $125(92 \%)$ & 0 & 1364.1 & $79.0-23528.3$ & $<0.0001$ \\
\hline Total & & $136(100 \%)$ & $62(100 \%)$ & & & \\
\hline
\end{tabular}

*The univariate analysis done to know the for possible association of analyzed variables and it predicted that male partners agedbetween 31-35 years doing mixed type of job for minimum 5-10 years have more chances of having abnormal sperm concentrations and motility with higher odds ratio (OD).

Table 1 represents demographic variables and semen parameters in male occupational workers and their comparison with control group. The maximum cases with abnormal semen parameters were observed in the age group of 31-35 years and were of primary infertility $(97.7 \%)$, one of the important observations of the study was industrial workers undergoing treatment for impaired semen parameters were working in arduous conditions $(47.7 \%)$. The maximum abnormal semen parameters were observed in $59.5 \%$ workers whose period of employment in the particular job was less than 5 years with reduced total sperm concentration from $<10$ million
(32\%) to no sperms (32\%) and the results were significant when compared to control group ( $p<0.05)$. In the study group abnormal semen count were observed in $114(83.2 \%)$ workers. $125(92 \%)$ of 136 patients presented with asthenozoospermia. The findings were significant $(\mathrm{p}<0.05)$ as compared to control group.

Table 2 shows association of male infertility with occupation of industrial workers i.e. arduous, hazardous or mixed category. The majority of workers with primary infertility $62(95.3 \%)$ with age more than 31 years were undertaking arduous jobs $27(41.5 \%)(\mathrm{p}=0.187)$. It was further observed from the study that 29 (44.6\%) workers 
were doing arduous jobs for minimum of 10 years of employment presented with abnormal semen parameters $52(96.3 \%)$ may be due to prolonged occupational exposure. The arduous workers also presented with abnormal sperm motility in $59(90.7 \%)$ and azospermia in $23(35.8 \%)$ with significant findings ( $\mathrm{p}<0.05)$. The workers who were in arduous job in the study group were further subdivided according to semen density 17 (26.1\%), males having semen density (total sperm count) $\geq 15 \times 10^{6} \mathrm{mln} / \mathrm{ml}, 9(13.8 \%)$ with TSC $10-15 \times 10^{6} \mathrm{mln} / \mathrm{ml}$ and $16(24.6 \%)$ males had TSC $<10 \times 10^{6} \mathrm{mln} / \mathrm{ml}$ and 23 $(35.8 \%)$ with no sperms or azoospermia.

Table 2: Association of demographic variable and semen parameters with type of employment in the study group.

\begin{tabular}{|c|c|c|c|c|c|c|}
\hline \multirow{2}{*}{ Variables } & & \multicolumn{3}{|c|}{ Type of employment } & \multirow{2}{*}{ Total } & \multirow{2}{*}{ p-value } \\
\hline & & Arduous & Hazardous & Mixed & & \\
\hline \multirow{6}{*}{ Age (years) } & $21-25$ yrs. & 6 & 0 & 4 & $10(7 \%)$ & \multirow{6}{*}{0.144} \\
\hline & $26-30 \mathrm{yrs}$ & 20 & 6 & 28 & $54(40 \%)$ & \\
\hline & $31-35$ yrs. & 27 & 10 & 18 & $55(40 \%)$ & \\
\hline & $36-40$ yrs. & 10 & 1 & 2 & $13(10 \%)$ & \\
\hline & $>40$ yrs. & 2 & 0 & 2 & $4(3 \%)$ & \\
\hline & Total & $65(48 \%)$ & $17(12 \%)$ & $54(40 \%)$ & $136(100 \%)$ & \\
\hline \multirow{3}{*}{ Type of infertility } & Primary infertility & 62 & 17 & 54 & $133(98 \%)$ & \multirow{3}{*}{0.187} \\
\hline & Secondary infertility & 3 & 0 & 0 & $3(2 \%)$ & \\
\hline & Total & $65(48 \%)$ & $17(12 \%)$ & $54(40 \%)$ & $136(100 \%)$ & \\
\hline \multirow{4}{*}{$\begin{array}{l}\text { Duration of } \\
\text { employment }\end{array}$} & Less than 5 yrs. & 21 & 6 & 54 & $81(60 \%)$ & \multirow{4}{*}{$<0.000$} \\
\hline & $5-10$ yrs. & 29 & 8 & 0 & $37(27 \%)$ & \\
\hline & More than 10 yrs. & 15 & 3 & 0 & $18(13 \%)$ & \\
\hline & Total & $65(48 \%)$ & $17(12 \%)$ & $54(40 \%)$ & $136(100 \%)$ & \\
\hline \multirow{5}{*}{$\begin{array}{l}\text { Total sperm count } \\
\text { (TSC) }\end{array}$} & $<10$ million/ml & 16 & 6 & 21 & $43(32 \%)$ & \\
\hline & $10-15$ million/ml & 9 & 1 & 17 & $27(20 \%)$ & \multirow{4}{*}{$<0.000$} \\
\hline & $>15$ million/ml & 17 & 3 & 2 & $22(16 \%)$ & \\
\hline & No sperms & 23 & 7 & 14 & $44(32 \%)$ & \\
\hline & Total & $65(48 \%)$ & $17(12 \%)$ & $54(40 \%)$ & $136(100 \%)$ & \\
\hline \multirow{3}{*}{$\begin{array}{l}\text { Total motility } \\
(A+B C D)\end{array}$} & Abnormal & 59 & 17 & 49 & $125(91.9 \%)$ & \multirow{3}{*}{0.425} \\
\hline & Normal & 6 & 0 & 5 & $11(8.0 \%)$ & \\
\hline & Total & $65(48 \%)$ & $17(12 \%)$ & $54(40 \%)$ & $136(100 \%)$ & \\
\hline
\end{tabular}

\section{DISCUSSION}

In the present study, the occupational workers who were undergoing treatment for primary infertility were either doing hazardous, arduous or mixed type of jobs and presented with significant reduction in the total sperm concentration. In study group, $83.2 \%$ of workers presented with abnormal semen parameters with majority (92\%) of them having asthenozoospermia within 5 years of employment. The present study also highlights the significant changes in semen parameters including total sperm count and sperm motility in male partners aged more than 31 years doing arduous jobs for minimum of 5 years. The alteration of semen parameters with age of male has direct correlation with nature and duration of employment. It was observed in the study that semen density decreases with age and confirms observation made by other authors. ${ }^{7-9}$

The division of males according to the occupation performed was based on literature reports directly or indirectly indicating the relation between a specified occupation and fertility disorders. ${ }^{10-12}$ There are many physio-chemical agents that lead to exposure in occupational workers and same have been reported to impair male fertility (Figure 1). The hazardous workers working in hot occupational environments with exposure to ionizing radiation or high temperature radiant heat as among welders, foundry workers, ceramic workers and bakers may cause reduced sperm count as reported by many studies. ${ }^{12-25}$ In this study, the men working in mixed type of employment were found to have maximum impaired semen parameters as compared to hazardous and arduous group. Studies have also demonstrated that there is significant decline in average sperm densities over the past in men sitting for work for eight hours a day with average $0.7^{\circ} \mathrm{C}$ higher scrotal temperature during the day. An increase of scrotal temperature in person day doing arduous jobs like in taxi drivers, computer operators, office clerks etc. may be sufficient to impair spermatogenesis and thus resulting in derailed semen parameters. ${ }^{26-32}$ In this study, men working in arduous 
conditions had severe oligospermia in $24 \%$ and $35.3 \%$ had no sperms.

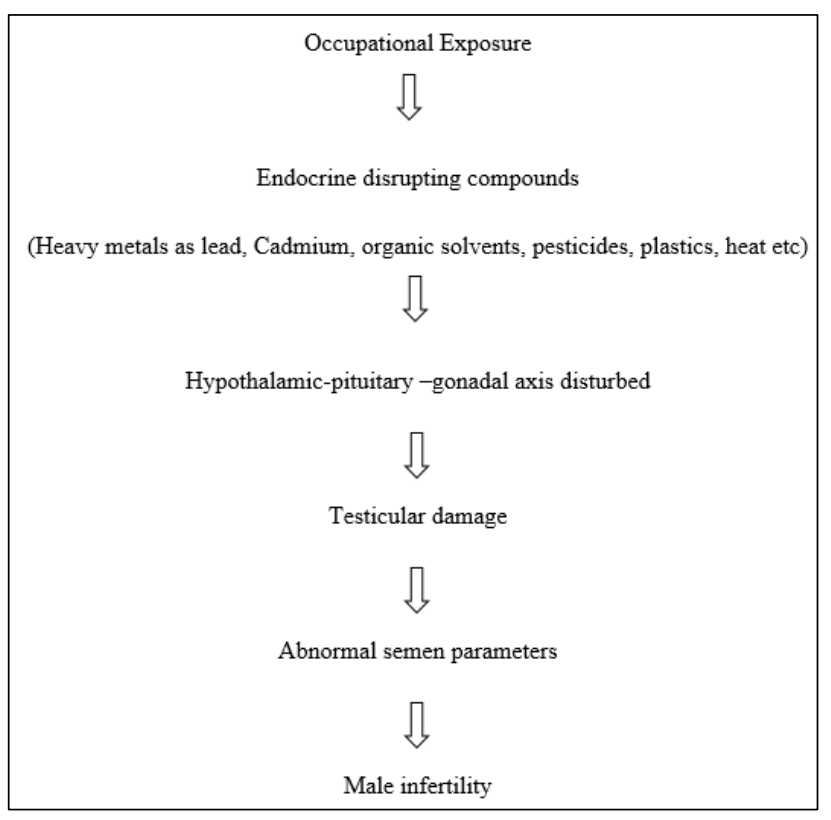

Figure 1: Mechanisms of male infertility attributed to occupational and lifestyle factors.

The present study suggests that working conditions of occupational workers influence male semen parameters. But there could be other confounding factors such as poor working conditions, hygiene, use of tobacco and alcohol intake can also attributes to altered semen parameters.

So, this is one of the limitations of the study and it is difficult to single out the role of any one workplace hazard such as occupational exposure conditions and it tends to be complex with multiple confounding variables such as smoking, alcohol consumption, diet and socioeconomic status etc. Any of these factors might have adverse effects on male reproductive function. ${ }^{26}$

The study included small sample size as a greater number of males needs to be included in future studies for getting robust epidemiological data. This study contributes additional information on the growing evidence linked to on job hazards leading to male fertility problems by impacting semen parameters. It is responsibility of employers and regulators to minimize exposure to the population from those toxins by use of proper personnel protecting equipment's and other safety precaution as required.

Education about reproductive health and potential hazards in the workplace is important for all workers. Further research is needed to help obtain further evidence-based data on the effect of occupation in organized sector industrial workers. This may help in achieving a better reproductive health of the workers by providing conductive working environment.
Funding: No funding sources

Conflict of interest: None declared

Ethical approval: The study was approved by Institutional Ethical Committee (CTRI No: CTRI/2018/11/016465)

\section{REFERENCES}

1. Carlsen E, Giwercman A, Keiding N, Skakkebaek NE. Evidence for decreasing quality of semen during past 50 years. BMJ. 1992;305:609-13.

2. Sharpe RM. Declining sperm counts in men-is there an endocrine cause? J Endocrinol. 1993;136:357-60.

3. Forti G, Serio M. Male infertility: is its rising incidence due to better methods of detection or an increasing frequency? Hum Reprod. 1993;8:1153-4.

4. Kumar S. Occupational exposure associated with reproductive dysfunction. J Occup Health. 2004;46(1):1-19.

5. Sheiner ETK, Sheiner E, Hammel R, Potashnik G, Carel R. Effect of occupational exposures on male fertility: literature review. Ind Health. 2003;41(2):5562.

6. Wdowiak A, Wdowiak L, Wiktor H. Evaluation of the effect of using mobile phone on male fertility. Ann Agric Environ Med. 2007:14:169-72.

7. Celina K, Wdowiak A, Anna BPK. The role of age, environmental and occupational factors on semen density Ann Agric Environ Med 2011: 18:437-40.

8. Radwan J. Infertility and the assisted reproduction techniques). Wyd Med Termed Wyd Poznań. 2005:33-40.

9. Schmid TE, Eskenazi B, Baumgartner A, Marchetti F, Young S, Weldon R, et al. The effects of male age on sperm DNA damage in healthy non-smokers. Hum Reprod. 2007;22(1):180-7.

10. Cherry N, Moore H, McNamee R, Pacey A, Burgess G, Clyma JA, et al. Participating centres of ChapsUK. Occupation and male infertility: glycol ethers and other exposures. Occup Environ Med. 2008;65(10):708-14.

11. Sheiner EK, Sheiner E, Carel R, Potashnik G, Vardi I. Potential association between male infertility and occupational psychological stress. J Occup Environ Med. 2002;44(12):1093-9.

12. Tas S, Lauwerys R, Lisom D. Occupational Hazards of the Male Reproductive System. Crit Rev Toxicol. 1996;26(3):261 - 307

13. Claman P. Men at risk: occupation and male infertility. Fertil Steril. 2004;81(2):19-26.

14. Joffe M. Infertility and environmental pollutants. Br Med Bull. 2003;68(1):47-70.

15. Fleurian G, Perrin J, Ecochard R, Dantony E, Lanteaume A, Achard V, ety al. Occupational exposures obtained by questionnaire in clinical practice and their association with semen quality. $\mathbf{J}$ Androl. 2009;30(5):566-79.

16. Jung A, Schuppe HC. Influence of genital heat stress on semen quality in humans. Androl. 2007;39(6):203-15. 
17. Kovacic P, Jacintho JD. Reproductive toxins: pervasive theme of oxidative stress and electron transfer. Curr Med Chem. 2001;8(7):863-92.

18. Multigner L, Ben Brik E, Arnaud I, Haguenoer JM, Jouannet P, Auger J, et al. Glycol ethers and semen quality: a cross-sectional study among male workers in the Paris Municipality. Occup Environ Med. 2007;64(7):467-73.

19. Naha N, Manna B. Mechanism of lead induced effects on human spermatozoa after occupational exposure. Kathmandu Univ Med J. 2007;5(1):85-94.

20. Oliva A, Spira A, Multigner L. Contribution of environmental factors to the risk of male infertility. Hum Reprod. 2001;16(8):1768-76.

21. Saradha B, Mathur PP. Effect of environmental contaminants on male reproduction. Environ Toxicol Pharmacol. 2006;21(1):34-41.

22. Whorton D. Pesticides: pesticide-induced infertility in male workers. occupational safety and health symposia 1978, division of technical services, NIOSH, Cincinnati, Ohio (Contract-210-78-0053). NIOSH. 1979:99-102.

23. Mieusset R, Bujan L. Testicular heating and its possible contributions to male infertility: a review. Int J Androl. 1995;18:169-84.

24. Talamanca I, Cini C, Varricchio GC. Effects of prolonged autovehicle driving on male reproduction function: a study among taxi drivers. Am J Industrial Med. 1996;30:750-8.

25. Thonneau P, Ducot B, Bujan L. Heat exposure as a hazard to male fertility. Lancet. 1996;347:204-5.

26. Swan SH, Elkin EP, Fenster L. The question of declining sperm density revisited: an analysis of 101 studies published 1934-1996. Environ Health Persp. 2000;108:961-6.

27. Mieusset R, Bujan L. Testicular heating and its possible contributions to male infertility: a review. Int J Androl. 1995;18:169-84.

28. Talamanca FI, Cini C, Varricchio GC. Effects of prolonged autovehicle driving on male reproduction function: A study among taxi drivers. Am J Industrial Med. 1996;30:750-8.

29. Thonneau P, Ducot B, Bujan L. Heat exposure as a hazard to male fertility. Lancet. 1996;347:204-5.

30. Bujan L, Daudin M, Charlet JP. Increase in scrotal temperature in car drivers. Human Reproduction. 2000;15:1355-7.

31. Stoy J, Hjollund NH, Mortensen JT. Semen quality and sedentary work position. Int $\mathrm{J}$ Androl. 2004;27:5-11.

32. Sheiner EK, Sheiner E, Hammel R, Potashnik G, Carel R. Effect of occupational exposures on male fertility: literature review. Ind Heal. 2003;41(2):5562.

Cite this article as: Wadhwa L, Fauzdar A, Wadhwa SN, Singh L, Chakravarti S, Kaur O. Association of occupational exposure on semen density in male industrial workers undergoing infertility treatment at tertiary care hospital. Int J Reprod Contracept Obstet Gynecol 2019;8:2453-8. 